\title{
PERBANDINGAN ANTARA MODEL PEMBELAJARAN KOOPERATIF TIPE STUDENT TEAMS ACHIEVEMENT DIVISION DENGAN TIPE TEAMS GAME TOURNAMENT TERHADAP HASIL BELAJAR MATEMATIKA SISWA KELAS VIII SMP NEGERI 8 KOTA BIMA
}

\author{
Rahman Setiawan $^{* 1}$, Sri Aryaningsyih ${ }^{1}$, Saifullah $^{1}$ \\ ${ }^{1}$ Program Studi Pendidikan Matematika, STKIP Bima \\ "Email korespondensi: rahman.setiawan@ gmail.com
}

\begin{abstract}
ABSTRAK
Jenis penelitian ini adalah Quasi Experiment (Eksperimen Semu). Populasi dalam penelitian ini adalah seluruh siswa kelas VIII SMP Negeri 8 kota Bima tahun pelajaran 2017/2018. Sampel diambil dengan menggunakan teknik purposive sampling sehingga diperoleh kelas VIII B sebagai kelas STAD (STUDENT TEAMS ACHIEVEMENT DIVISION) dan VIII C sebagai kelas TGT (TIPE TEAMS GAME TOURNAMENT). Pengambilan data penelitian dengan menggunakan instrumen tes. Teknik analisis data dalam penelitian ini dibagi menjadi dua tahap, yaitu uji persyaratan analisis dan uji hipotesis. Uji prasyarat analisis dengan menggunakan uji normalitas dan uji homogenitas. Analisis uji hipotesis menggunakan uji- $t$ untuk sampel independen. Hasil tes menunjukan kelas STAD dengan jumlah siswa 21 orang, memperoleh rata-rata hasil belajar matematika (74.19) dengan varians (43.96). Sedangkan kelas TGT dengan jumlah siswa 21 orang, memperoleh rata-rata hasil belajar matematika (72.85) dengan varians (34.02). Dengan membandigkan rata-rata hasil belajar matematika siswa menggunakan model pembelajaran kooperatif tipe STAD dan tipe TGT dikelas VIII SMP Negeri 8 kota Bima. Dapat dilihat bahwa rata-rata model STAD lebih dari rata-rata model TGT. Jadi ada perbedaan dalam penerapan kedua model tersebut pada kelas VIII SMP Negeri 8 Kota Bima.
\end{abstract}

Kata Kunci : Pembelajaran Kooperatif Student Teams Achievement Division, Teams Game Tournament, Hasil Belajar Matematika

\begin{abstract}
This type of research is Quasi Experiment. The population in this study were all eighth grade students of Bima City Middle School 8 in school year 2017/2018. Samples were taken using purposive sampling technique to obtain class VIII B as STAD and VIII C classes as TGT classes. Retrieval of research data using test instruments. The data analysis technique in this study is divided into two stages, namely test requirements analysis and hypothesis testing. Analysis prerequisite test using normality test and homogeneity test. Hypothesis test analysis uses the t-test for independent samples. The test results show the STAD class with a total of 21 students, obtaining an average of mathematics learning outcomes (74.19) with variance (43.96). While the TGT class with a total of 21 students, obtained an average mathematics learning outcome (72.85) with variance (34.02). By comparing the average mathematics learning outcomes of students using the cooperative learning model type STAD and type TGT in class VIII, SMP Negeri 8, city of Bima. It can be seen that the average STAD model
\end{abstract}


is more than the average TGT model. So there are differences in the application of the two models in class VIII of SMP Negeri 8 Kota Bima.

Keywords : Cooperative Learning Student Teams Achievement Division, Game Tournament Teams, Mathematics Learning Result

\section{PENDAHULUAN}

Sebagai salah satu lembaga yang menyelenggarakan pendidikan formal, sekolah mempunyai peranan penting dalam usaha mendewasakan siswa agar menjadi anggota masyarakat yang berguna, untuk tujuan tersebut, sekolah menyelenggarakan kegiatan belajar mengajar dan kurikulum sebagai wadah dan bahan mentahnya. Matematika adalah proses memperoleh pengetahuan yang dibangun oleh siswa sendiri dan harus dilakukan sedemikian rupa sehingga dapat memberikan kesempatan kepada siswa untuk menemukan kembali konsep- konsep matematika.

Matematika dianggap sangat penting bagi kehidupan manusia karena matematika memiliki keterkaitan dan menjadi pendukung berbagai bidang ilmu serta berbagai aspek bidang kehidupan manusia. Tetapi matematika juga dianggap sebagai suatu mata pelajaran yang cukup sulit bagi banyak siswa. Ketidaksenangan siswa terhadap matematika salah satunya dikarenakan siswa mengalami ketidaktuntasan dalam menyerap materi pelajaran. Sedangkan ketidak tuntasan tersebut disebabkan siswa mengalami masalah dalam belajar. Salah satu masalah dalam belajar adalah siswa tidak dapat menyerap informasi yang diberikan. Hal ini disebabkan oleh kurangnya minat dan motivasi belajar siswa terhadap pelajaran matematika serta metode yang digunakan oleh guru dalam proses belajar dan mengajar matematika kurang tepat, sehingga siswa sulit berprestasi dalam pembelajaran matematika.

Berdasarkan salah satu penelitian dari Fitriana (2010) yang berjudul "Pengaruh Model Pembelajaran Cooperative Tipe Group Investigation (GI) dan STAD Terhadap Prestasi Belajar Matematika Ditinjau Dari Kemandirian Belajar Siswa”. Hasil penelitian menunjukkan bahwa terdapat pengaruh model pembelajaran terhadap prestasi belajar matematika materi Bangun Ruang Sisi Datar. Pada siswa-siswa yang diberi pembelajaran dengan model pembelajaran cooperative tipe GI lebih baik prestasi belajarnya dibandingkan dengan siswa-siswa yang diberi pembelajaran dengan model pembelajaran cooperative tipe STAD. 2. Terdapat 
pengaruh kemandirian belajar terhadap prestasi belajar matematika materi Bangun Ruang Sisi Datar. Pada mereka yang mempunyai kemandirian belajar tinggi lebih baik prestasi belajarnya dibandingkan dengan mereka yang mempunyai kemandirian belajar sedang maupun yang mempunyai kemandirian belajar rendah, dan mereka yang mempunyai sedang sama prestasi belajarnya dibandingkan dengan mereka yang mempunyai kemandirian belajar rendah. Tidak terdapat interaksi antara model pembelajaran cooperative dengan kemandirian belajar siswa terhadap prestasi belajar geometri pokok bahasan bangun ruang sisi datar siswa SMP/MTs di Kota Surakarta. Sehingga baik pada model pembelajaran cooperative tipe STAD maupun tipe GI, mereka yang mempunyai kemandirian belajar tinggi lebih baik prestasi belajarnya dibandingkan dengan mereka yang mempunyai kemandirian belajar sedang, dan mereka yang mempunyai kemandirian belajar sedang sama prestasi belajarnya dengan mereka yang mempunyai kemandirian belajar rendah, sedangkan pada kategori tingkat kemandirian belajar tinggi, mereka yang diberi pembelajaran dengan model pembelajaran cooperative tipe GI lebih baik prestasi belajarnya dibandingkan dengan mereka yang diberi pembelajaran dengan model pembelajaran cooperative tipe STAD. Tidak demikian halnya, pada kategori tingkat kemandirian belajar sedang maupun tingkat kemandirian belajar rendah, pemberian pembelajaran dengan model pembelajaran cooperative tipe STAD maupun tipe GI tidak menyebabkan perbedaan prestasi belajar.

Berdasarkan hasil wawancara dengan salah seorang guru matematika di SMP N 8 Kota Bima menyatakan bahwa hasil belajar matematika disekolah ini masih rendah. Rendahnya hasil belajar matematika terlihat dari nilai rata-rata yang diperoleh siswa belum mencapai kriteria ketuntasan minimum (KKM) yaitu (65) yang ditetapkan sekolah.Rendahnya hasil belajar siswa dipengaruhi oleh faktor dari siswa maupun metode yang digunakan, belum mengenai sasaran. Hal ini dibuktikan dari sebelumnya guru matematika pernah menerapkan beberapa metode dalam pembelajaran matematika. Adapun faktor dari siswa yang mempengaruhi rendahnya hasil belajar siswa antara lain: (1) Siswa tidak memperhatikan dan tidak fokus saat guru menjelaskan. (2) Siswa menganggap pelajaran matematika pelajaran membosankan. (3) siswa tidak mau bertanya, meskipun belum memahami materi pelajaran matematika yang diajarkan tersebut.

Untuk mengatasi permasalahan diatas, salah satu usaha yang harus dilakukan guru matematika adalah mengoptimalkan keberadaan siswa sebagai objek dan sekaligus subjek 
pembelajaran, maksud objek pembelajaran karena siswalah yang menerima materi pembelajaran, sedangkan subjek pembelajaran karena yang aktif dalam kegiatan pembelajaran tidak selalu guru. Artinya siswapun perlu diaktifkan dalam kegiatan pembelajaran.

Salah satu cara yang dapat digunakan guru untuk mengaktifkan siswa adalah dengan menggunakan pembelajaran kooperatif (cooperative learning). 1) Pembelajaran kooperatif merupakan sebuah kelompok strategi pengajaran yang melibatkan siswa bekerja secara berkolaborasi untuk mencapai tujuan bersama. 2) Pembelajaran kooperatif disusun dalam sebuah usaha untuk meningkatkan pertisipasi siswa, menfasilitasi siswa, serta memberikan kesempatan pada siswa untuk berinteraksi dan belajar bersama-sama siswa yang berbeda latar belakangnya. 3) Dalam belajar kooperatif, siswa dibentuk dalam kelompok-kelompok yang terdiri dari $4-5$ orang untuk bekerja sama dalam menguasai materi yang diberikan guru.

Terdapat banyak tipe model pembelajaran kooperatif, diantaranya Student Teams Achievement Division (STAD) dan Teams Games Turnaments(TGT). STAD dan TGT merupakan bentuk pembelajaran kooperatif yang paling tua dan paling banyak diteliti. Slavin (2016:143) juga mengemukakan STAD merupakan salah satu metode pembelajaran kooperatif yang paling sederhana dan merupakan model yang paling baik untuk permulaan bagi paraguru yang baru menggunakan pendekatan kooperatif . Sedangkan TGT memiliki kemiripan dengan STAD, yakni mengganti kuis pada STAD dengan turnamen.

Tapi permasalahannya tidak ada yang bisa menjamin bahwa suatu model pembelajaran akan selalu berhasil untuk diterapkan pada semua peserta didik dan pada setiap pokok bahasan. Untuk itu ingin dilakuka npenelitian tentang "Perbandingan Hasil Belajar Matematika Siswa Antara Model Pembelajaran Kooperatif Tipe Student Teams Achievement Division (STAD) Dengan Tipe Teams Games Turnaments (TGT) di Kelas VIII SMP N 8 KOTA BIMA

\section{METODE PENELITIAN}

Jenis penelitian yang digunakan dalam penelitian ini adalah Quasi experiment (Eksperimen semu) dimana peneliti menerima apa adanya kelompokatau kelas yang sudah ada sehingga tidak memungkinkan untuk menempatkan subjek secara random kedalam kelompokkelompoknya. Menurut Sugiyono (2016:114) Eksperimen semu adalah penelitian yang 
mempunyai kelompok kontrol, tetapi tidak berfungsi sepenuhnya untuk mengontrol variablevariabel luar yang mempengaruhi pelaksanaan eksperimen.

Teknik pengumpulan data merupakan langkah yang paling strategis dalam penelitian, karena tujuan utama dari penelitian adalah mendapatkan data. Data-data dalam penelitian ini dikumpulkan dengan pemberian tes menggunakan lembar tes. metode penelitian yang digunakan adalah uji $t$.

\section{HASIL DAN PEMBAHASAN}

Berdasarkan data hasil tes yang diberikan kepada kelas eksperimen 1 dengan model pembelajaran kooperatif tipe STAD dengan jumlah siswa sebanyak 21, diperoleh data sebagai berikut yang menunjukkan bahwa dari 21 siswa diperoleh nilai rata-rata 74.19, dengan varians 43.96, standar deviasi/simpang baku 6.63. Berdasarkan tes hasil belajar matematika pada kelas eksperimen 1, diperoleh nilai terendah 65 dan nilai tertinggi 88.

Data hasil tes yang diberikan kepada kelas eksperimen 2 dengan model pembelajaran kooperatif tipe TGT dengan jumlah siswa sebanyak 21 diperoleh bahwa nilai rata-rata 72.85, dengan varian 34.02, standar deviasi/simpang baku 5.83 dengan tes hasil belajar matematika pada kelas eksperimen 2, diperoleh nilai terendah 68 dan nilai tertinggi 85.

Berdasarkan skor tes dari kedua kelas penelitian yaitu kelas STAD dan kelas TGT. selanjutnya skor tes diolah dengan menggunakan Chi Kuadrat atau Chi Squere untuk menguji normalitas. Dari hasil pengujian untuk kelas eksperimen 1 (STAD) diperoleh nilai $x^{2}$ Hitung $=-40.08$ dan dari nilai tabel $x^{2}$ uji chi kuadrat atau chi squere diperoleh nilai $x^{2}$ tabel $=x^{2}{ }_{(1-\infty)(d k)}$ pada taraf signifikan $\propto=0.05$ adalah 5.99. Karena $x^{2}$ hitung kurang dari $x^{2}$ tabel atau $(-40.08 \leq 5.99)$ maka $_{0}$ diterima. Maka varians berdistribusi normal.

Dari hasil pengujian untuk kelas eksperimen 2 (TGT) diperoleh nilai $x^{2}$ hitung= - 14.14(lampiran 19) dan dari nilai tabel $x^{2}$ uji chi kuadrat atau chi squere diperoleh nilai $x^{2}$ tabel $=x_{(1-\infty)(d k)}^{2} \quad$ pada taraf signifikan $\propto=0.05$ adalah 5.99. Karena $x^{2}$ hitung kurang dari $x^{2}$ tabel atau $(-14.14 \leq 5.99)$. Maka $\mathrm{h}_{0}$.varians berdistribusi normal. Selanjutnya, dilakukan uji homogenitas varians terhadap data tersebut untuk dua kelas yaitu kelas eksperimen 1 kelas STAD dan kelas eksperimen 2 kelas TGT dengan menggunakan uji F dengan hasil bahwa kedua kelompok data adalah homogen. 
Berdasarkan hasil uji prasyarat menunjukan bahwa data berdistribusi normal dan homogen, maka selanjutnya data dianalisis untuk pengujian hipotesis. Perhitungan uji hipotesis dilakukan untuk mengetahui ada atau tidaknya perbedaan hasil belajar matematika siswa yang menggunakan model pembelajaran kooperatif tipe STAD dan model pembelajaran kooperatif tipe TGT. Hasil uji t dapat dilihat pada tabel berikut ini.

Tabel 1. Uji tes " $\mathrm{t}$ "

\begin{tabular}{cccccc}
\hline kelas & Rata-rata & $\mathrm{t}_{\text {hitung }}$ & $\mathrm{df}$ & $\mathrm{t}_{\text {tabel }}$ & $\mathrm{H}_{0}$ \\
\cline { 5 - 6 } & & & & $5 \%$ & \\
\hline STAD & 74.19 & 0.69 & 40 & 2.02 & diterima \\
TGT & 72.85 & & & & \\
\hline
\end{tabular}

Pada tabel diatas dapat dilihat bahwa untuk hasil belajar dari perhitungan " $t$ " diperoleh nilai rata-rata sebesar 74.19 untuk model pembelajaran kooperatif tipe STAD , 72.85 untuk kooperatif tipe TGT. Nilai $t_{\text {hitung }}$ yang diperoleh dari hasil perhitungan lebih kecil dari $t_{\text {tabel }}$ pada taraf signifikan $\propto=0.05$, yang berarti $\mathrm{H}_{0}$ diterima.

Perbedaan rata-rata kedua variabel menunjukan bahwa penggunaan model pembelajaran kooperatif tipe STAD lebih baik dari pada model pembelajaran kooperatif tipe TGT. Dimana rata-rata hasil belajar kelas yang menggunakan pembelajaran kooperatif tipe STAD sebesar 74.19 dan rata-rata hasil belajar kelas yang menggunakan pembelajaran kooperatif TGT sebesar 72.85.

Berdasarkan hasil belajar siswa pada pokok bahasan Operasi Aljabar menunjukan bahwa rata-rata hasil belajar kelas yang menggunakan pembelajaran kooperatif tipe STAD lebih tinggi dari rata-rata hasil belajar kelas yang menggunakan pembelajaran kooperatif tipe TGT.

Dari perhitungan tes " $\mathrm{t}$ " diperoleh $t_{\text {hitung }}$ lebih kecil dari $t_{\text {tabel }}$ atau $=0.695 \leq$ 2.02 pada taraf signifikan 5\%. Hal ini menunjukkan bahwa penerapan model pembelajaran kooperatif tipe STAD dalam pembelajaran matematika berpengaruh positif karena adanya perbedaan hasil belajar matematika siswa khususnya pada pokok bahasan Operasi Aljabar di SMP Negeri 8 Kota Bima Tahun 2017/2018, dimana hasil belajar kelas STAD lebih tinggi dari kelas TGT. Perbedaan mean kedua variabel menunjukan bahwa penggunaan model 
pembelajaran kooperatif tipe STAD lebih baik dari pada pembelajaran kooperatif tipe TGT.Dapat dilihat pada tabel berikut ini.

Tabel 4.8: Perbandingan Rata-Rata Eksperimen 1 (STAD) dan Eksperimen 2 (TGT)

\begin{tabular}{cccc}
\hline Kelas & Rata-rata & varians & Standar deviasi \\
\hline Eksperimen 1(STAD) & 74.19 & 43.46 & 6.63 \\
Eksperimen 2 (TGT) & 72.85 & 34.02 & 5.83 \\
\hline
\end{tabular}

Pada tabel di atas menunjukan bahwa kelas eksperimen 1 dengan menggunakan model pembelajaran kooperatif tipe STAD lebih baik dari kelas eksperimen 2 dengan menggunakan model pembelajaran kooperatif tipe TGT,yang di tunjukan dengan rata-rata kelas eksperimen 1 dengan menggunakan model pembelajaran kooperatif tipe STAD sebesar 74.19 sedangkan kelas eksperimen 2 dengan model pembelajaran kooperatif tipe TGT dengan rata-rata sebesar 72.85. Dengan demikian hasil analisis ini mendukung rumusan masalah yang diajukan yaitu ada perbedaan hasil belajar matematika siswa menggunakan model pembelajaran kooperatif tipe student teams achievemen division (STAD) dan Team Games Tournament (TGT) di SMP Negeri 8 Kota Bima.

\section{KESIMPULAN}

Setelah data penelitian diperoleh dengan menggunakan instrumen ukur yang disusun peneliti dan dilakukan pengujian hipotesis, maka dapat diambil kesimpulan bahwa terdapat perbedaan yang signifikan antara hasil belajar siswa yang menggunakan model pembelajaran kooperatif tipe STAD dengan siswa yang menggunakan model pembelajaran kooperatif tipe TGT. Ini terlihat berdasarkan perbandingan $t_{\text {hitung }}$ dengan $t_{\text {tabel }}$ pada taraf signifikan $5 \%$ menunjukan $t_{\text {hitung }}$ lebih kecil dari $t_{\text {tabel }}(0.69 \leq 2.02)$.Dan dapat dilihat dari perbedaan ratarata kedua modeI pembelajaran tersebut. model pembelajaran kooperatif tipe STAD dengan rata-rata 74.19 dan model pembelajaran kooperatif tipe TGT dengan rata-rata 72.85,yang menunjukan bahwa model STAD lebih efektif dari model TGT.

\section{REKOMENDASI}

Untuk meningkatkan hasil belajar siswa dalam pembelajaran matematika diharapkan guru mata pelajaran dapat mempertimbangkan penggunaan model pembelajaran kooperatif tipe STAD dan TGT ini. Dengan model ini selain dapat meningkatkan hasil belajar 
matematika, diharapkan dapat menciptakan suasana yang menyenagkan yang interaktif dan efektif dalam mencapai tujuan pembelajaran

Kepada peneliti lanjutan yang ingin melakukan penelitian serupa dapat mencobakan pada tempat dan materi yang berbeda. Bagi calon peneliti yang ingin menerapkan pembelajaran kooperatif ini dalam penelitiannya, maka harus meluangkan waktu khusus untuk menjelaskan metode tersebut kepada siswa dan juga mengenalkan siswa dengan tugas-tugas, tujuan dan struktur penghargaan.

\section{REFERENSI}

Arifin, Z. (2012). Evaluasi Pembelajaran, Prinsip, Teknik, Prosedur. Bandung: Remaja Rosdakarya.

Darmadi, H. (2014). Metode Penelitian Pendidikan. Bandung: Alfabeta.

Priansa, D. J. (2017). Pengembangan Strategi Model Pembelajaran: Inovatif, Kreatif dan Prestatif Dalam Memahami Peserta Didik .Bandung :Cv Pustaka Setia

Slameto. (2015). Belajar dan Faktor-faktor yang Mempengaruhi. Jakarta: PT.Renika Cipta.

Slavin, R. (2016). Cooperative Learning; Teori, Riset dan Praktik. (diterjemahkan: NarulitaYusron). Bandung: NusaMedia.

Syah, M. (2015) . Psikologi Belajar .Jakarta : Raja wali Pers.

Sudijono, A. (2009). Pengantar Evaluasi Pendidikan. Jakarta:Rajawali Pers.

Sudjana, N. 2010. Penilaian Hasil Proses Belajar Mengajar. (Cet. XV). Bandung: PT. Ramaja Rosdakarya.

Sugiyono.(2016). Metode Penelitian Kuantitatif, Kualitatif dan R\&D. Bandung: Alfabeta. , sehingga siswa sulit berprestasi dalam pembelajaran matematika.

Fitriana, L. (2010). Pengaruh Model Pembelajaran Cooperative Tipe Group Investigation (GI) dan STAD Terhadap Prestasi Belajar Matematika Ditinjau Dari Kemandirian Belajar Siswa. Tesis. Universitas Sebelas Maret Surakarta. 